\title{
UJI AKTIVITAS ANTI JAMUR EKSTRAK DAUN API-API (Avicennia marina VIERH) UNTUK MENGHAMBAT PERTUMBUHAN JAMUR Schizophyllum commune FRIES
}

(Anti-Fungal Activity of Api-Api Leaf Extract (Avicennia marina Vierh) to Inhibit the Growth of Schizophyllum commune Fries)

\author{
Agus Setiawan, Farah Diba, Evy Wardenaar \\ Fakultas Kehutanan Universitas Tanjungpura Pontianak. J1. Daya Nasional Pontianak 78124 \\ e-mail : agsina1212@gmail.com
}

\begin{abstract}
The aim of the study was to extract Avicennia marina Vierh leaf and used for anti-fungal against Schizophyllum commune Fries, and to evaluate the best concentration of extract A. marina in inhibiting the growth of S.commune fungi. The leaf of A. marina was found in Bakau Kecil village in Mempawah Regency. The leaf was made into particle with size 40-60 mesh then extracted with methanol in ratio 1:5 (w/v). The extract of A. marina leaf was made into concentration $0 \%, 1 \%, 2 \%, 3 \%, 4 \%$, and $5 \%$. The extract then poured into PDA and one cell of S. commune fungi was put in the center of PDA, The bioassay of evaluation the inhibition of fungal growth was conducted on seven days. After seven days the anti-fungal activity was measured. Result of the research showed that the growth of fungi on concentration 1\% was $35.62 \mathrm{~mm}$; on concentration $2 \%$ was $33.17 \mathrm{~mm}$ and on concentration $3 \%$ was $27.09 \mathrm{~mm}$. Meanwhile on concentration 4\% and 5\% the fungi was not growth, either from the first day until the end of bioassay at the seven days. Vice versa on control ( $0 \%$ concentration) the fungal growth until the all of the petri dish with average $91.40 \mathrm{~mm}$. Concentration of extract A. marina leaf $4 \%$ and concentration $5 \%$ was classified in very strong anti-fungal activities. E xtract methanol of A. marina leaf with concentration $4 \%$ can be used to inhibition the S. commune fungi with very strong anti-fungal activities.
\end{abstract}

Keywords : Anti fungal, Avicennia marina Vierh, leaf, Schizophyllum commune Fries, wood preservation

\section{PENDAHULUAN}

Ketersediaan kayu semakin terbatas terutama kayu kelas awet I dan II, di samping harganya yang mahal sehingga masyarakat beralih menggunakan kayu kelas awet III dan IV yang mempunyai tingkat keawetan alami rendah. Kayu kayu yang memiliki kelas awet rendah cenderung mudah rusak oleh faktor biologis. Salah satu faktor biologis tersebut adalah jamur pelapuk kayu. Pengaruh serangan jamur pada kayu secara mekanik akan menyebabkan penurunan kekuatan kayu karena komponen-komponen dinding sel yang menguatkan kayu telah dihancurkan. Salah satu jamur pelapuk kayu adalah $S$. commune Fries. Suprapti dan Djarwanto (2000) menyatakan jamur $S$. commune dikenal sebagai jamur pelapuk kayu yang ganas karena dapat menyerang buah, biji-bijian, rotan, bambu dan kayu. Jamur ini dapat ditemukan di seluruh lokasi di Indonesia.

Kayu yang memiliki kelas awet rendah akan sangat mudah terserang 
oleh faktor-faktor perusak kayu yang mengakibatkan menurunnya umur pakai kayu. Salah satu cara yang dapat dilakukan untuk meningkatkan umur pakai kayu adalah dengan pemberian bahan pengawet pada kayu. Pada umumnya bahan pengawet yang digunakan pada saat ini masih bertumpu pada bahan kimia sintetis yang memiliki dampak negatif bagi lingkungan dan manusia karena bahan kimia tersebut sulit terdekomposisi dan berbahaya bagi kesehatan manusia.

Salah satu cara untuk meningkatkan umur pakai kayu yaitu dengan memanfaatkan pengawet alami yang diperoleh dari zat ekstraktif tanaman (Sari dan Hadikusumo, 2004). Zat ekstraktif merupakan senyawa metabolit sekunder yang terdapat pada rongga sel yang dapat dimanfaatkan sebagai bahan pengawet alami. Ditinjau dari segi ekologis, senyawa metabolit sekunder ini memiliki dampak positif terhadap lingkungan karena dapat terdekomposisi (biodegradeble). Selain dapat terdekomposisi dengan baik di alam, bahan-bahan alami tersebut juga bersifat terbaharukan dan mudah diperoleh karena ketersediaannya yang melimpah.

Semakin bertambahnya jumlah penduduk kebutuhan akan kayu semakin meningkat dan banyaknya kayu yang rusak disebabkan faktor biologis perusak kayu dan semakin berkurangnya kayu dengan kualitas baik sehingga perlu dilakukan pengawetan supaya kayu yang memiliki kekuatan rendah dapat digunakan untuk mengatasi akibat menurunnya ketersediaan kayu yang memiliki kelas awet baik, cara yang baik untuk mengatasi masalah tersebut adalah dengan cara pemberian bahan pengawet dan juga memanfaatkan tumbuhan alami yang ada di sekitar yang dapat dijadikan sebagai bahan pengawet yang ramah lingkungan

Salah satu tumbuhan yang berpotensi sebagai bahan pengawet alami adalah ekstrak daun api-api ( $A$. marina Vierh). Penelitian Afzal et al. (2011) melakukan ekstraksi daun api api (A.marina Vierh) dan digunakan sebagai anti jamur dan mengatasi penyakit alergi kulit. Tumbuhan yang mempunyai kandungan senyawa aktif sebagai insektisida adalah dari golongan flavonoid dan terpenoid. Daun api - api memiliki kandungan senyawa dari golongan flavonoid dan terpenoid. Oleh karena itu perlu dilakukan penelitian untuk penggunaan ekstrak daun api api sebagai bahan penghambat pertumbuhan jamur pelapuk kayu Schizophyllum commune Fries. Tujuan penelitian adalah menguji daya hambat dari ekstrak daun api - api A. marina Vierh terhadap pertumbuhan jamur $S$. commune, menguji konsentrasi terbaik dari ekstrak daun api - api A. marina Vierh dalam menghambat pertumbuhan jamur S.commune dari setiap konsentrasi yang di uji.

\section{METODOLOGI PENELITIAN}

Penelitian dilaksanakan di Laboratorium Teknologi Kayu Fakultas Kehutanan Universitas Tanjungpura Pontianak, dengan waktu penelitian \pm 3 (tiga) bulan, dimulai bulan Februari 
sampai dengan bulan April 2018 mulai dari persiapan ekstrak, pengerjaan dan pengujian sampai pengolahan data. Kultur murni jamur Schizophyllum commune Fries yang diperoleh dari Laboratorium Teknologi Kayu Fakultas Kehutanan Universitas Tanjungpura Pontianak. Daun Avicennia marina diperoleh dari Desa Bakau Kecil Kabupaten Mempawah.

\section{Persiapan Sampel Daun Api-api} (Avicennia marina)

Daun api-api yang telah diambil dibersihkan dengan cara dilap menggunakan kain basah yang bertujuan untuk menghilangkan benda asing yang ada pada permukaan daun dan diangin-anginkan selama 1 hari. Selanjutnya daun dikering ovenkan pada suhu $40^{\circ} \mathrm{C}$ selama 8 hari sampai mencapai berat konstan (Mangrio et al, 2016). Setelah kering selanjutnya dibuat serbuk dengan menggunakan blender dan disaring dengan meshscreen berukuran 40-60 mesh yang bertujuan untuk mendapatkan serbuk daun api-api yang seragam.

Pembuatan Ekstrak Daun Api-api (A. marina)

Pembuatan ekstrak daun api - api mengacu kepada penelitian Handa et al. (2008), dengan urut - urutan pekerjaan sebagai berikut : Sebanyak 200 gram serbuk daun api-api dimasukkan ke dalam botol reagent dan dimaserasi menggunakan pelarut metanol dengan perbandingan volume antara serbuk dan pelarut yaitu 1 : 5 berat/volume. Selanjutnya dikocok menggunakan sheker selama \pm 48 jam dengan kecepatan 150-200 rpm. Selanjutnya larutan tersebut disaring dengan menggunakan kertas saring, kertas saring yang digunakan adalah kertas saring meteran, dan kemudian kertas saring diletakkan diatas corong kaca dan ditampung dalam erlenmeyer. Perlakuan maserasi diulang hingga di dapatkan hasil ekstrak yang cukup untuk pengujian sehingga tidak kekurangan ekstrak pada saat pengujian, dengan perbandingan berat/volume yang sama seperti langkah awal maserasi. Selanjutnya larutan ekstrak metanol tersebut diuapkan menggunakan rotary evaporator pada suhu berkisar antara $45-50{ }^{\circ} \mathrm{C}$. Kemudian larutan tersebut diletakkan diatas water bath $60-70 \quad{ }^{\circ} \mathrm{C}$ hal ini dilakukan agar sisa-sisa pelarut didalam ekstrak menguap dan di dapatkan hasil ektrak yang kental.

Perhitungan Rendemen Ekstrak Daun Api-api (A. marina)

Rendemen ekstrak daun api-api mengacu pada Sunanto (2003). Perhitungan rendemen ekstrak daun apiapi dilakukan dengan cara menimbang simplisia api-api sebelum diekstraksi dan berat ekstrak hasil ekstraksi. Besarnya rendemen dihitung dengan rumus sebagai berikut:

$$
\text { Rendemen (R) }=\frac{A}{B} x 100 \%
$$

Keterangan :

$\mathrm{R}=$ Rendemen ekstrak daun api-api (\%)

$\mathrm{A}=$ Berat ekstrak (gr)

$\mathrm{B}=$ Berat serbuk sebelum diekstrak (gr) 
Pembuatan Konsentrasi Ekstrak Daun Api-api (A. marina)

Pengujian terdiri atas 6 taraf konsentrasi larutan ekstrak yaitu $0 \%$, $1 \%, 2 \%, 3 \%, 4 \%, 5 \%$. Perhitungan jumlah ekstrak yang diperlukan pada masing-masing tingkat konsentrasi dengan jumlah larutan sebanyak $10 \mathrm{ml}$.

Pengukuran aktivitas anti jamur atau Anti Funggal Activity (AFA)

Pengukuran pada pertumbuhan koloni yaitu dengan mengukur diameter koloni jamur, dengan metode titik dua garis bantu diameter yang saling tegak lurus satu dengan yang lain dibawah cawan petri dan pengukuran menggunakan kaliper digital bertututturut selama 7 hari. Pengukuran pada aktivitas anti cendawan menggunakan rumus Mori et al (1997) sebagai berikut

$$
\mathrm{AFA}=\frac{G C-G T}{G C-A} \times 100 \%
$$

\section{Keterangan :}

$\mathrm{AFA}=$ Aktivitas anti jamur

$\mathrm{GC}=$ Pertumbuhan miselium kontrol $(\mathrm{mm})$

GT=Pertumbuhan miselium dalam medium berekstrak ( $\mathrm{mm}$ )

$\mathrm{A}=$ Ukuran miselium awal inkubasi (mm)

Analisis Data

$$
\text { Penelitian menggunakan }
$$

Rancangan Acak Lengkap (RAL) dengan 6 taraf konsentrasi dan 3 kali ulangan. Perlakuan adalah tingkat konsentrasi ekstrak daun api - api $(A$. marina Vierh) yang meliputi $0 \%$ (Kontrol), 1\%, 2\%, 3\%, 4\%, dan 5\%.

HASIL DAN PEMBAHASAN

Rendemen daun api - api A. marina

Rendemen ekstrak daun api - api A. marina adalah sebesar $27,08 \%$ dengan ekstrak yang didapatkan sebanyak 0,2709 gr dan hasil ekstrak berwarna hijau pekat dan berbentuk kental.

Penghambatan pertumbuhan jamur $S$. commune Fries

Rerata diameter pertumbuhan jamur $S$ commune Fries pada perlakuan control $(0 \%)$ pada hari ke -7 mencapai 91,40 mm dan memenuhi seluruh cawan petri. Sementara itu pada konsentrasi $1 \%$ rerata pertumbuhannya yaitu sebesar 35,62 mm. Konsentrasi 2\% rerata pertumbuhannya yaitu sebesar $33,17 \mathrm{~mm}$. Konsentrasi 3\% rerata pertumbuhannya yaitu sebesar 27,09 mm. Konsentrasi 4\% dan konsentrasi 5 $\%$ rerata pertumbuhannya hanya sebesar 6,47 mm, yang merupakan diameter awal dari jamur. Dengan demikian pada konsentrasi 4\% dan konsentrasi 5\% tidak ada pertumbuhan jamur. Grafik rerata pertumbuhan jamur disajikan pada Gambar 1. 


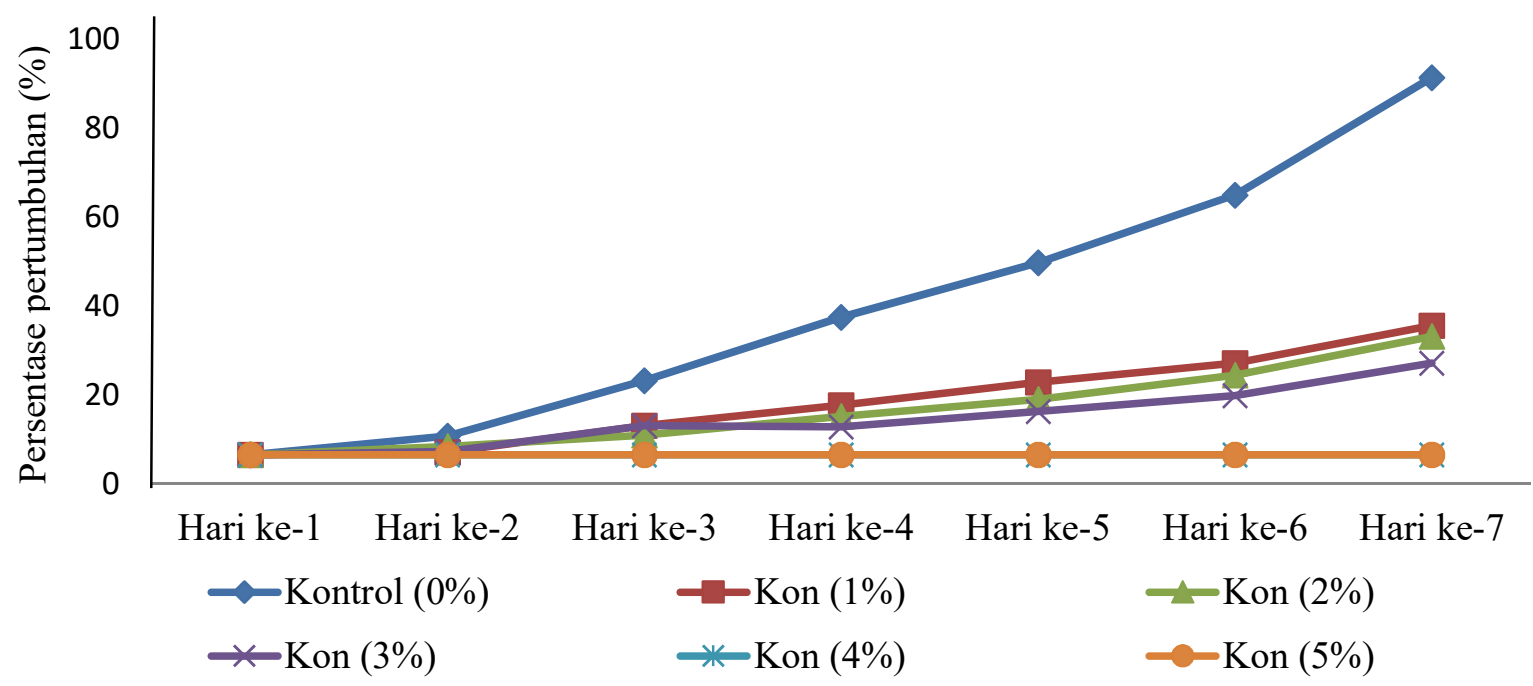

Gambar 1. Nilai rerata pertumbuhan jamur Schizophyllum commune pada media yang telah diberi ekstrak methanol daun Api-api (Avicenia marina) pada konsentrasi yang berbeda (Average value of the growth of fungal Schizophyllum commune on media with extract methanol of leaf Api-api (Avicenia marina) on different concentration)

Aktivitas Anti Jamur atau Anti Fungal Activity (AFA)

Nilai rerata aktivitas anti jamur dari ekstrak methanol daun api-api (Avicennia marina) adalah sebesar $54,82 \%$ sampai $90,00 \%$. Nilai rerata aktivitas anti jamur pada konsentrasi $1 \%$ sebesar $54,82 \%$, kemudian pada konsentrasi $2 \%$ sebesar $55,93 \%$ kemudian pada konsentrasi 3\% sebesar $61,73 \%$. Nilai rerata aktifitas anti jamur pada konsentrasi $4 \%$ dan 5\% masing-masing memiliki nilai yang sama yaitu $90 \%$.

Konsentrasi ekstrak daun api - api $A$. marina dari nilai AFA yang sangat kuat terdapat pada konsentrasi $4 \%$ dengan persentase aktivitas anti jamurnya sebesar 90\%. Namun apabila dibandingkan dengan hasil penelitian yang dilakukan Pasaribu (2015) persentase yang optimum terjadi pada konsentrasi $10 \%$ dengan tingkat penghambatan sebesar 78,39\%, selain itu penelitian yang dilakukan Sudarmadi et al (2013) persentase AFA yang optimum ada pada konsentrasi $10 \%$ dengan daya hambat sebesar $80,08 \%$, dan hasil penelitian Sari (2013) persentase AFA yang optimum terdapat pada konsentrasi $2 \%$ dengan daya hambat sebesar 97,62 \%.

Kandungan kimia yang terdapat pada daun api - api A. marina yaitu triterpenoid, steroid, alkaloid, flavonoid, saponin, dan juga tannin. Penelitian yang dilakukan Pasaribu (2015) yang menggunakan ekstrak dari minyak atsiri kulit jeruk pelarut metanol kandungan yang terdapat pada kulit jeruk mengandung seperti terpen, sesquiterpen, aldehida, ester, dan sterol. Penelitian yang dilakukan Sudarmadi (2013) yang menggunakan ekstrak minyak sindur dengan pelarut metanol, kandungan yang ada pada minyak kayu sindur seperti sesquiterpen, 
hidrokarbon, sesquiterpen oxide, dan sesquitepen alcohol. Penelitian yang dilakukan Sari (2013) yang menggunakan ektrak dari bonggol bunga teratai yang mana menggunakan pelarut metanol, kandungan yanag terdapat pada bonggol bunga teratai seperti alkaloid, saponin, dan tanin. Hasil penelitian yang dilakukan oleh Yisa (2009), tumbuhan teratai memiliki alkaloid (rendah), saponin (sedang), dan tanin (rendah).

Persentase dari daya hambat perumbuhan dari jamur $S$. commune berbeda - beda karena dari penelitian yang dilakukan, meskipun pelarut yang digunakan sama, dan kandungan kimia dari masing - masing bahan yang digunakan berbeda - beda sehingga daya hambat dari serangan jamur $S$. commune juga berbeda - beda terutama dari konsentrasi yang digunakan menentukan hasil akhirnya untuk daya hambat dari jamur $S$. commune seperti hasil penelitian yang dilakukan Pasaribu (2015) yang menggunakan bahan minyak atsiri dari kulit jeruk yang mana konsentrasi optimal $10 \%$ sudah cukup untuk menghambat pertumbuhan jamur S. commune. Berbeda dengan yang dilakukan Sudarmadi (2013) yang menggunakan minyak kayu sindur yang konsentrasi optimumnya $10 \%$ juga sudah mampu menghambat pertumbuhan dari jamur $S$. commune, dengan kandungan dari minyak kayu sindur yang mana daya hambatnya cukup besar dengan konsentrasi yang tinggi, dan juga dilihat dari hasil penelitian yang dilakukan Sari (2013) menggunakan bonggol dari bunga teratai yang konsentrasi optimumnya sebesar $2 \%$ untuk ekstrak dapat menghambat pertumbuhan dari jamur $S$. commune, dari semua bahan yang digunakan dan kemungkinan besar dari perbedaan konsentrasi dan hasil daya hambat atas serangan jamur $S$. commune dari bahan - bahan yang digunakan kandungan yang ada di dalam masing masing bahan juga berbeda walaupun menggunakan pelarut yang sama tetapi hasil akhir yang didapatkan berbeda beda sehingga faktor daya hambatnya juga berbeda selain dari faktor lingkungan, tempat tumbuh, dan cara ekstraksinya yang memungkinkan hasil akhir dari tanaman itu sendiri untuk menghambat serangan dari jamur S. commune.

Berdasarkan hasil penelitian yang telah dilakukan uji aktivitas anti jamur ekstrak daun api - api terhadap pertumbuhan jamur $S$. commune dengan hasil optimum yang dipilih berdasarkan kategori nilai AFA yang sangat kuat $(\geq$ $75 \%$ ) dengan tingkat konsentrasi yang paling kecil, maka konsentrasi yang optimum dalam menghambat pertumbuhan jamur $S$. commune adalah pada konsentrasi $4 \%$ dengan daya hambat sebesar $100 \%$ dengan tingkat aktivitas anti jamur sangat kuat.

\section{KESIMPULAN DAN SARAN}

Ekstrak daun api -api Avicenia marina larut metanol dapat menghambat pertumbuhan jamur Schizophyllum commune Fries. Konsentrasi ekstrak daun api - api sebesar 4\% merupakan konsentrasi yang sangat optimal dalam menghambat pertumbuhan dari jamur $S$. commune dengan daya hambat sangat kuat sebesar $100 \%$ dan mematikan. 
Hasil penelitian yang dilakukan dapat dilanjutkan dengan uji aktivitas ektrak daun api - api $A$. marina yang langsung diaplikasikan untuk mengawetkan kayu. Hasil penelitian menunjukkan ada faktor faktor yang mempengaruhi keefektifan penggunaan ektrak daun api - api $A$. marina, maka dari itu sebaiknya dilakukan penelitian lebih lanjut dengan metode ektraksi dan konsentrasi pelarut yang berbeda, supaya dapat mengetahui apakah ektrak daun api - api A. marina tersebut dapat menghambat atau bahkan dapat lebih mematikan dari serangan jamur $S$. commune.

\section{DAFTAR PUSTAKA}

Afzal M, Masood R, Jan G, Majid A, Fiaz M, Shah AH, Alam J, Mehdi FS, Abbasi FM, Ahmad H, Islam M, Inamullah, Amin NU. 2011. Efficasy of avicennia marina (Forsk) Vierh. leaves extracts againts some atmospheric fungi. African Journal of Biotecnology 10 (52) :10790-10794.

Handa SS, Khanuja SPS, Longo G, Rakesh DD. 2008. Extraction Technology for Medicinal and Aromatic Plants. Trieste: United Nations Industrial Development Organization and the International Centre for Science and High Technology.

Mangrio AM, Rafiq M, Navqi SHA, Junejo SA, Mangrio SM, Rind NA. 2016. Evaluation of Phytocemical Constituent and Antibacterial Potential of Avicennia marina and Rhizopora mucronata From Indus Delta of Pakistan. 13 (4) :259-265.

Mori, M., M. Aoyama, S. Dci, A. Kanetoshi, and T. Hayashi. 1997.
Antifungal activity of bark extracts of deciduous trees holzalsRoh und werkstoff. 55: 130 -132 . Springer - verlage.

Pasaribu, S.M.H. Wardenaar, E. Wahdina. 2015. Uji aktivitas anti jamur ekstrak minyak atsiri kulit jeruk (Citrus nobilis var.microcarpa) terhadap pertumbuhan jamur Schizophyllum commune Fries. Jurnal Hutan Lestari 3(2) : 259264.

Sari, E.P. Wardenaar, E. Yusro, F. Aktivitas ekstrak metanol bonggol bunga teratai (Nymphaea Lotus L.) untuk pengendalian cendawan pelapuk kayu Schizopyllum commune Fries Secara In Vitro. Jurnal Hutan Lestari 1(3) : 252 257

Sari, L. dan Hadikusumo, S. 2004. Daya racun ekstrak kulit pucung terhadap rayap kayu kering (Cryptotermes cynochephalus Light). Jurnal Ilmu dan Teknologi Kayu Tropis 2. https://scholar.google.co.id/schola r. [ 20 Maret 2019]

Sudarmadi, B. Diba, F. Yanti, H. 2013. Uji aktivitas anti jamur ekstrak minyak kayu sindur (Sindora wallichi Benth) terhadap pertumbuhan jamur Schizophyllum commune Fries. Jurnal Hutan Lestari 1(2).

Sunanto, H. 2003. Budi Daya dan Penyulingan Kayu Putih. Yogyakarta : Kanisius.

Suprapti S dan Djarwanto, 2000. Kemampuan Sepuluh Isolat Jamur Dalam Melapukkan Kayu. Prosiding Seminar Nasional III. Fahutan UNWIM - Janinangor. 
JURNAL HUTAN LESTARI (2019)

Vol. 7 (1) : 517 - 524

Yisa. Jonathan. 2009. Phytochemical analysis and antimicrobial activity of Scopariadulicis and
Nyamphaea lotus. Australian Journal of Basic and Appled Sciences. 3 (4), 3975 - 3979. 